\title{
The Practice Exploration of Micro English course in College English Teaching
}

\author{
Nan $\mathrm{Li}^{1}$, Jingjing Guan ${ }^{1}$, Yang Liu ${ }^{1}$, Di Yan ${ }^{1}$, Xueyan Sun ${ }^{1}$ \\ ${ }^{1}$ Qiqihar Medical University, Qiqihar Heilongjiang Province, China
}

Keywords: Micro course, College English teaching, applied research

\begin{abstract}
With the development of information and communication technology, a new type of teaching resources, micro class into reality in the classroom, it will change traditional way of teaching and research. How to design, develop, and implement the lesson is current research hotspot issues, this article takes the college English education as the background, to explore the micro lessons into real classroom teaching mode.
\end{abstract}

\section{Introduction}

At present, the ministry of education is also in class actively promoting micro this kind of new teaching methods. The ministries of education of the two units are actively promoting micro class competition. One is the education management information center and north of anonymous group cooperation, micro class competition for primary and secondary school teachers. Another is the ministry of education's nationwide network of university teachers' training center organization of micro teaching competition first national colleges and universities [1]. In addition to the push of ministry of education, in many provinces, municipalities, autonomous regions and their subordinate administrative department of education, is also actively promote the design, development and application of micro class. Under this background, the micro class and professional English teaching organically, will help to improve the students' learning interest and learning effect, to strengthen the professional English application ability and professional ability of students, so that the students can meet the needs of future positions and career development.

With the continuous development of information technology and communication technology, we start to go to the micro age micro cultural pursuit, Weibo, micro film, tiny said, WeChat continuously rise and rapid development. The rapid development of society and people's high rhythm of life, also makes the whole period of time to study less and less, people urgently calls for a simple, convenient, fun and efficient carrier of learning [1]. And the popularity of network technology, and constantly create a new space for the new study way, the generation of micro course, satisfy people fast food type of learning, so that they can use spare time to learning and thinking. Micro course also in the broader needs and application becomes a kind of new teaching and learning resources.

\section{An overview of the micro course}

Micro course because just started, for what it is, of course, the definition of vary, but it's not the concept of hype, is not a slogan called out again.

Micro courses and miniature, first invented by the American college of New Mexico, SAN Juan David Penrose, refers to the video as the main carrier, record the teacher education, both inside and outside the classroom teaching process around a certain knowledge or teaching link and the whole process of teaching and learning activities [2]. Micro class content is the core of classroom teaching video, at the same time also includes teaching design, the material relevant to the subject matter and the teaching courseware, teaching reflection and practice tests and student feedback, the teacher reviews, auxiliary teaching resources, relationship to a certain organization and presentation "to create" the resources unit application of one and a half structured, the topic type "environment". Therefore, the class is different from the traditional single resource type of lesson example, teaching courseware, teaching design, teaching reflection and teaching resources, and on the basis of the inheritance and development of a new type of teaching resources [2]. Micro courses in addition to the 
micro video as the core of teaching resources, and also involves situation introduced before class, after class, learning evaluation conclusion, the student/teacher interaction, namely video, auxiliary learning resources, interactive exchange platform of integrated micro class system.

\section{The characteristics of the micro class}

Short and lean. The so-called "class", first performance in its time is very short - the video is generally in about 10 minutes. Of course, its teaching content is relatively small. In a short time, based on the school resources, the ability of the teachers and student's interest, micro class formed relatively independent and complete small courses. It change numerous for brief, short, only to learn the core content, not learn, just learn need most, only to learn the most useful. It is a simplified, subdivision of the teaching process, students and therefore easy to master.

The key content. "Class" only around a certain knowledge or teaching link to carry out teaching activities, thus the teaching goal clear, focused. Relative to the traditional classroom, the teaching activities is more clear and focused. It makes the students and teachers may focus on a specific teaching behavior.

Rich resource. "Class" video of classroom teaching as the core, but are not limited to a single video materials. It is a composed of numerous resources three-dimensional, diversified resources package: can include teachers do the teaching design, multimedia teaching courseware, course practice, related testing, teaching evaluation, teaching reflection and multimedia material, etc.

Class of flexible learning. Students can watch in addition to the class teacher provide micro video class, can also according to own actual need in their spare time to watch over and over again at any time. Thinking when to learn, when to learn, even if only a few minutes. A number of "time" can be combined into "1 $+1>2$ " effect of learning, the characteristics is shown in below Fig.1.

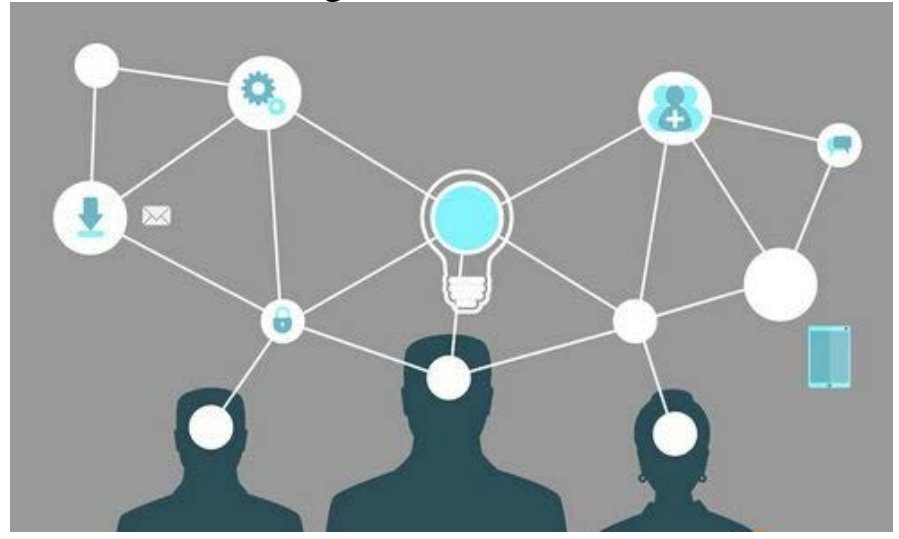

Fig.1 Flexible learning of micro class

\section{Micro class introduction of English classroom teaching mode}

Classroom teaching is not independent of a link, we will complete the teaching process is divided into: in this class analysis and teaching design, classroom teaching and after-school evaluation study of three parts [3]. Micro class as a structured, interactive teaching environment, it is by the design document, teaching resources, courseware, case, material, etc.), video, interactive communication platform and learning evaluation system composed of a complete system. In the teaching process of each link can be introduced in the class, in combination with micro course resources provided by the implementation of classroom teaching better.

Class analysis and teaching design. Analysis is the foundation of teaching design before class, class analysis include: learning, teaching tasks, teaching content analysis. Focuses on learners' learning analysis by analyzing features of the students, according to the characteristics of the learners identify targets through the teaching should have the knowledge and ability to target. After determine the learning objectives for teaching task analysis and the analysis of teaching content, teaching task and teaching content should be around teaching goal design. Micro platform of learning evaluation function can be used as the basis of analysis before class. Instructional design is based on the teaching 
goal and the teaching object to arrangement of the elements of teaching optimization form the process of teaching plan. In the task driven teaching instructional design can be divided into the content in the design of design and process design [3]. Content design mainly course content structure design, according to the course content is divided into a number of child content or knowledge. Process design is mainly design learning situation. In the process of teaching design, teaching design documents provided by the micro class platform and teaching resources are the important resources.

The classroom teaching implementation. Classroom teaching is one of the most important link in the whole teaching process, the competence-based courses teaching mode, the emphasis on the working process of the guide, highlight the students' ability. Introduction course design teaching circumstances, given that task, this course good course tasks should be according to the actual professional activities, enterprises as the background, according to the requirements of epistemology in modified a specific task, task situation is true as far as possible, students are interested in. Knowledge about the new knowledge in the course is expounded and explanation, this step can also after the preliminary practice ability [4]. And students' ability is the practice process, from easy to difficult, from completely imitate the cat "to improve imitation of difficulty, until further improve" as the cat dog ", after repeated practice ability of students in the process of improving. In the process of classroom teaching implementation, micro class platform provides teaching resources; especially the video can be injected fresh energy to the classroom teaching.

\section{The application of micro courses in college English teaching}

Micro course as a tool of the "four modernizations" function, as well as a new type of more and more get the favor of the teachers and students and teaching resources, and in teaching and learning will become increasingly play an irreplaceable role.

In terms of micro course situation at present in China, at the beginning of the development is mainly for the professional development of teachers, and for students, parents, school, etc. The development later is mainly because the course first is as a tool to be used, not only become the teacher of the new way, and is born out of the used for the teaching of the curriculum resources.

Change the form, accelerate the development of teachers. Traditional professional research involves the background, significance, theoretical basis, is trying, and theory of considerable depth. But not everyone can play, while micro course from side real small problem, small phenomenon, in the school of the layers of analysis and research, finally solved the problems of this reality, and in like manner to the micro research process to make [4]. Due to the starting point of theory and technology are very low, so everyone can participate in and turn into micro research courses, teachers in the whole process unconsciously also get growth.

The application of the micro class specialized English teaching. In order to be able to change the status quo of college English teaching, improve the students' interest in learning, to promote teachers' teaching ability, promoting the fusion of information technology and subject teaching at the same time, in the English teaching in colleges and universities, the application of micro class can yet be regarded as a kind of beneficial attempt, will produce good results [5]. In English teaching in colleges and universities, "small class" can be applied in classroom teaching, and online autonomous learning, teachers' professional development, etc.

Micro course of "four modernizations" the teacher became the micro course developers, is also one of the consumer, the course with its unique charm, make teachers in-depth summary continuously in the development and utilization of the link, careful observation and depth of thinking. In creating a good micro course also virtually improve teachers' quality and ability [5]. Below Fig. 2 is the course as a tool to promote teachers' growth and model for the birth of a high quality learning resources. 


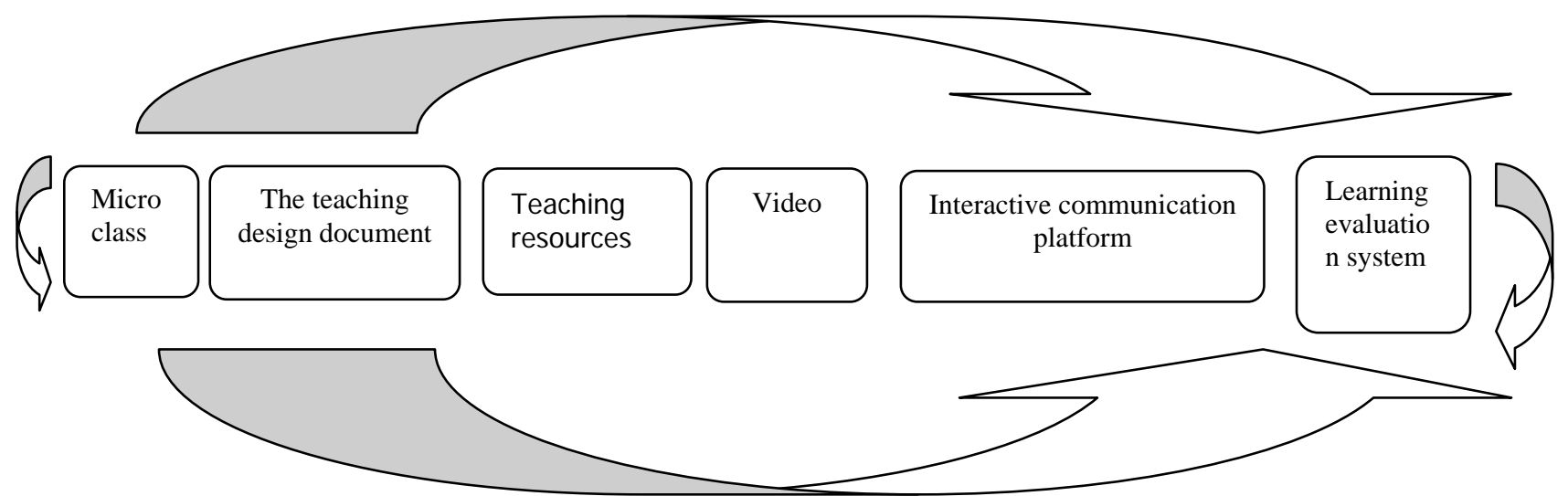

Fig.2 Micro class promotes the growth of the teachers and students learning resources development pattern

Students' autonomous learning. The popularity of the development of modern network and computer made it possible to autonomous learning. By the American college of salmon, reverse the classroom effects, such as the online teaching video, micro lesson is widely used in online learning. Especially in recent years, the course of design and development is more and more simple and convenient, the application of micro class also increasingly popular. After teacher making micro uploaded to the Internet, then students can demand at any time, at any time to watch, autonomous learning [6]. Micro class used in institutions of higher learning professional English autonomous learning of the student, has the following benefits:

1) Slightly short. Relative to the lengthy learning material, students prefer this form of learning. Professional English articles usually relatively long, students learn to feel boring to understand. The small class learning content is divided into small pieces; students learn up will be relatively easy. Even just understand a little knowledge, for students will have a great sense of accomplishment.

2) The flexible learning ways. Students can choose their own time and place to study at any time, autonomous learning space is large, as long as willing to learn. Learning is no longer confined to the classroom, don't again and again in the face of the book on the long professional vocabulary and professional articles. The autonomy, the greater the students' reverse psychology will reduce. By accumulate over a long period; the students learned knowledge is growing.

3) Suitable for different levels of students' learning. Institutions of higher learning of students' English level is uneven, the emergence of micro class can solve the problem of student's level differences. Micro lesson video can be played repeatedly, different levels of students can choose according to their own learning situation for their own video viewing. They can for their learning problems more efficiently. This basis for poor students and its selectivity is stronger, rather than in a traditional classroom, the teacher can't teach content repeatedly, if they don't understand, most of the students also embarrassed to ask questions.

WeChat classroom teaching. Micro class as a teaching video, the first can be flexible used in classroom teaching, import, the course focuses on the difficulties, used in teaching, after class to expand teaching links. Due to the emergence of the "class", the boring becomes vivid and many professional English classes, students can get more attention [7].

1) Review the old lessons. In English teaching, the teacher can according to the teaching requirements, make the old class to review the video, let the students after class to watch, to consolidate what they learned. Whether that many specialized in professional English vocabulary, terminology, and the core content of each unit, can be through the review after class to consolidate.

2) Import new lesson. Teachers can according to the new theme design, elaborate video as the import material, let the students watch at first class and attract their attention, generate interest in learning. In addition, a lot of thematic unit need to master certain professional knowledge, teachers can make relevant video material, let the students know the related content, which runs smoothly into the learning of this unit.

3) The difficulties in teaching. In the teaching of specialized English, because involves both professional knowledge, and there was a language barrier, there are always some difficult to 
understand the difficulties of knowledge for students to understand. Fully read the discussion, teachers can help students by watching video, explanation, schemata and list ways to let students have more intuitive understanding of the difficulties of knowledge.

4) Development practice. $n$ teaching class, the teacher can set aside some extend to watch video for students after class. These classes can be related reading materials, introduces the relevant professional knowledge and practice test, guides the student to expand knowledge, and summarizes the key, practice to improve.

\section{Summary}

Micro course has been developed in recent years a new type of teaching resources, the advantages of micro class makes it will have a good application prospect. Introduces micro class classroom teaching, there are some difficulties, because each lesson video is shorter, the content is limited, so that class platform knowledge is distributed, and in the complex situation of teaching requires comprehensive use all kinds of skills and knowledge, the introduction of micro lessons in the process of how to manage the series multiple knowledge, systematic is one of the important problems to solve. In addition, now China's micro class platform is less, the development is not mature, some problem such as platform to charge a fee, make the wide application of micro class by resistance. Communication and application is the ultimate goal of micro class platform construction, so the construction of more and better, nonprofit micro course platform, micro class will have very broad application prospect of education.

\section{Acknowledgement}

Project: 2016 medical education research project of "Education branch of Chinese medical association and Medicine Education association professional committee of China's higher education”, Project Number: 2016B-FF054.

\section{References}

[1] Ch.T. Liu, The micro study reviews software Tribune, Education technology, 2011, vol.3, pp. 6-8.

[2] Zh.T. Zhu, The usage of micro learning, informal learning mode, Audio-visual education in China, 2008, vol.2, pp.10-13.

[3] X.Y. Wang, Micro course - innovations on their ways of learning, Basic education course, 2013, vol.11, pp.94-95.

[4] J.B. Liu, Constructs the micro study ecosystems - based on new mode of teacher training course, Information technology education in China, 2012, vol.6, pp.9-11.

[5] J.T Liang, The development and application of micro course, Journal of education, 2012, vol.5, pp:28-32.

[6] B.Z. Xu, The application of micro courses in English teaching, Basic education course, 2010, vol.12, pp.9-13.

[7] L.M. Liang and Q.Q. Cao, The curriculum design pattern research---based on the contrastive analysis of the micro course at home and abroad, Open education research, 2013, vol.1, pp.65-73. 